\title{
Prediction of Specific Biomolecule Adsorption on Silica Surfaces as a Function of pH and Particle Size
}

By

Fateme S. Emami ${ }^{\dagger}$, Valeria Puddu ${ }^{\ddagger}$, Rajiv J. Berry ${ }^{\S}$, Vikas Varshney ${ }^{\S}$, Siddharth V. Patwardhan",

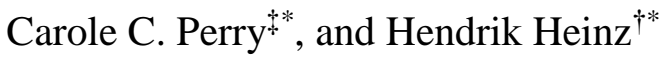

$\dagger$ Department of Polymer Engineering, University of Akron, Akron, Ohio 44325-0301, USA

Interdisciplinary Biomedical Research Centre, School of Science and Technology, Nottingham Trent University, Clifton Lane, Nottingham NG11 8NS, UK

$\S$ Materials and Manufacturing Directorate, Air Force Research Laboratory, Wright-Patterson Air Force Base, Ohio 45433, USA

" Department of Chemical and Process Engineering, University of Strathclyde, 75 Montrose Street, Glasgow G1 1XJ, UK

* Corresponding authors: carole.perry@ntu.ac.uk, hendrik.heinz@uakron.edu 


\begin{abstract}
Silica nanostructures are biologically available and find wide applications for drug delivery, catalysts, separation processes, and composites. However, specific adsorption of biomolecules on silica surfaces and control in biomimetic synthesis remain largely unpredictable. In this contribution, the variability and control of peptide adsorption on silica nanoparticle surfaces is explained as a function of $\mathrm{pH}$, particle diameter, and peptide electrostatic charge using molecular dynamics simulations with the CHARMM-INTERFACE force field. Adsorption free energies and specific binding residues are analyzed in molecular detail, providing experimentally elusive, atomic-level information on the complex dynamics of aqueous electric double layers in contact with biological molecules. Tunable contributions to adsorption are described in the context of specific silica surface chemistry, including ion pairing, hydrogen bonds, hydrophobic interactions, and conformation effects. Remarkable agreement is found for computed peptide binding as a function of $\mathrm{pH}$ and particle size versus experimental adsorption isotherms and zetapotentials. Representative surface models were built using characterization of the silica surfaces by TEM, SEM, BET, TGA, $\zeta$-potential, and surface titration measurements. The results show that the recently introduced interatomic potentials (Emami et al. Chem. Mater. 2014, 26, 2647) enable computational screening of a limitless number of silica interfaces to predict the binding of drugs, cell receptors, polymers, surfactants, and gases under realistic solution conditions at the scale of 1 to $100 \mathrm{~nm}$. The highly specific binding outcomes underline the significance of the surface chemistry, $\mathrm{pH}$, and topography.
\end{abstract}




\section{Introduction}

Silicon dioxide, or silica, is widely available in mineral form, biologically enriched in organisms, and produced by laboratory synthesis. ${ }^{1-3}$ It is extensively used as a filler material in nanocomposites and tires, in separation media for liquids and gases, cosmetics, catalyst supports, and building materials. Porous silica nanoparticles that exploit specific interactions with biological molecules in aqueous solution are also used in drug delivery systems, biomarkers, sensors, and nano-reactors. ${ }^{4-10}$ The performance for this broad range of applications is often still evaluated by trial and error and results remain difficult to explain. For example, efforts to synthesize silica from precursors to replicate hierarchically organized silica-protein skeletons similar to diatoms, marine organisms, $, 11,12$ and plants have shown first successes in achievable structural order. ${ }^{7,9,13-17}$ However, fundamental insight into mechanisms and control of assembly remains incomplete even though many amino acid sequences, peptides and proteins from microorganisms, cellular templates, and designed ligands were tested. ${ }^{6-10,14,18}$

Therefore, better understanding of the role of the precursors, of the surface chemistry of silica formed, as well as of the competitive interactions with solvents and proteins could provide significant benefits to the rational engineering of silica-based materials. The effect of synthesis conditions, $\mathrm{pH}$, buffer composition, and molecular conformation on materials formation is known to be critical. ${ }^{9}, 19,20$ However, limitations of current laboratory instrumentation pose difficulties to answer questions related to silica biomineralization and specific molecular recognition at the scale of 1 to $100 \mathrm{~nm}$ while complementary guidance from simulations can be very helpful. ${ }^{9,18,21-36}$

Studies by biopanning and molecular simulation with the polymer consistent force field (PCFF) extended to silica recently identified a range of contributions to specific adsorption of 
peptides on amorphous silica particles. ${ }^{9,} 10,26$ These contributions include ion pairing between positively charged groups in the peptides and siloxide groups on the silica surface accompanied by neutralization of the $\zeta$-potential, hydrogen bonds, van-der-Waals interactions with the surface, and conformation effects. The significance of each of these adsorption modes was found to depend on experimental conditions such as $\mathrm{pH}$, peptide sequence, and silica surface chemistry. As a consequence, the nature and strength of the interactions can only be identified using dedicated molecular models that represent closely the experimental conditions.

The aim of this contribution is the atomic-scale visualization of the binding process and quantitative predictions of specific adsorption of peptides to all types of silica surfaces using computer simulations. A companion paper recently introduced accurate force field parameters and a detailed surface model database for silica, ${ }^{37}$ which are employed here in the form of the CHARMM-INTERFACE force field. ${ }^{26}$ This study focuses on the effects of $\mathrm{pH}$ and particle size that modulate ionization, surface structure, and specific peptide adsorption (Figure 1)..$^{9,38-41}$ The chosen peptides include consensus silica binding sequences composed of seven amino acids with different net charge $(-1,0,+1)$ and hydrophilicity that were previously identified by phage display (Table 1). ${ }^{10}$ The chosen nanoparticles are of diameters $28 \mathrm{~nm}, 82, \mathrm{~nm}$, and $210 \mathrm{~nm}$, and have undergone characterization of their surface chemistry by BET, BJH, TGA, TEM, SEM, and $\zeta$-potential measurements (Figure 1). ${ }^{42}$

The outline of this paper is as follows. The recently introduced force field and surface model database for silica interfaces are briefly reviewed (section 2). Specific peptide adsorption, binding free energies, and mechanisms of interaction with silica surfaces are described as a function of $\mathrm{pH}$ and particle size, illustrating predictive details from simulation (section 3). A summary of the major results and conclusions follows at the end (section 4). The Supporting 
Information provides full details of computational and experimental methods, experimental data employed for validation, as well as further information (sections S1 to S4).
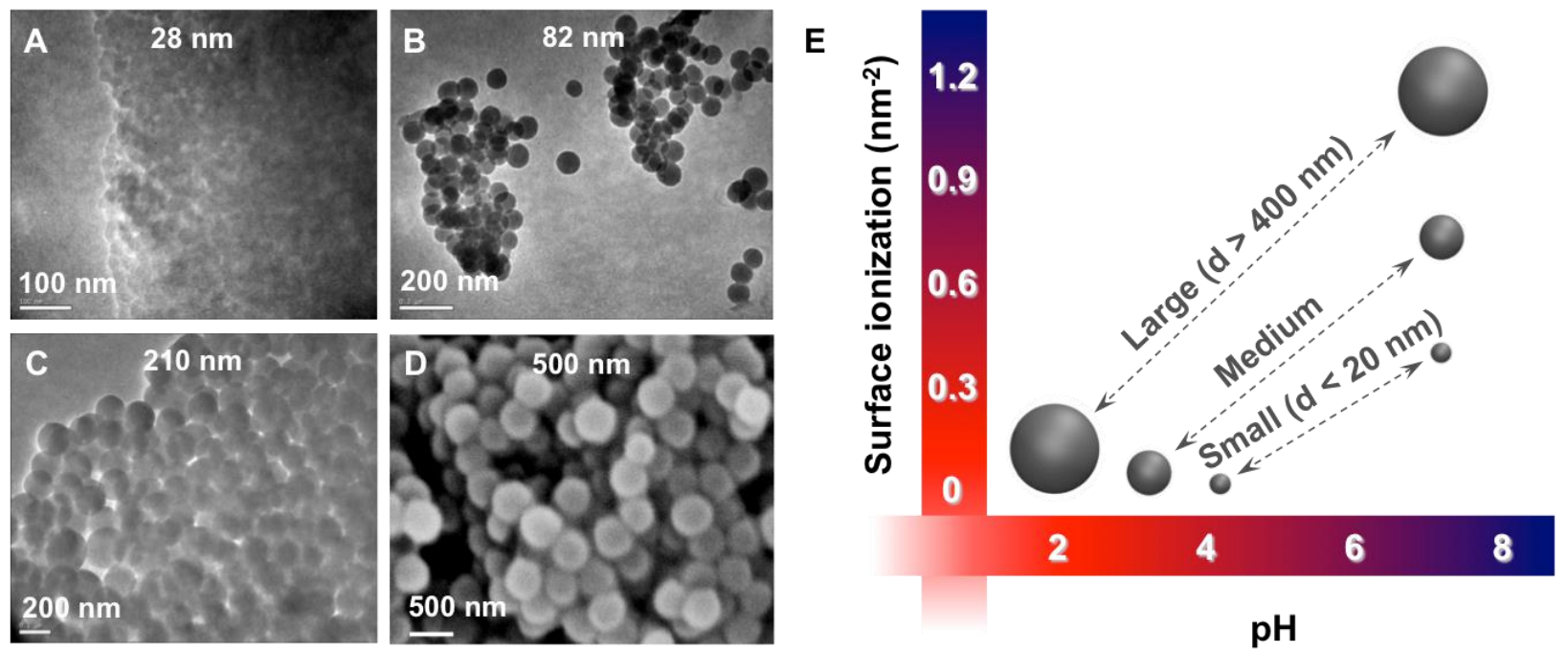

Figure 1. Electron microscopy images of amorphous silica nanoparticles of different size from Stöber-type synthesis, and the effect of $\mathrm{pH}$ and particle size on surface ionization (from refs. ${ }^{42,37}$ ). (A-D) TEM and SEM images for nanoparticles of average sizes 28, 82, 210, and $500 \mathrm{~nm}$ $\left(\right.$ ref. ${ }^{42}$ ). Silica nanoparticles of size $28 \mathrm{~nm}$ are less dense and poorly defined in comparison to spherical larger particles. (E) Schematic relationship between surface ionization, $\mathrm{pH}$, and particle size. Large nanoparticles contain $\mathrm{Q}^{2} / \mathrm{Q}^{3}$ surface environments, medium size and smaller nanoparticles contain mostly $\mathrm{Q}^{3}$ environments. The amount of $\mathrm{SiO}^{-} \mathrm{Na}^{+}$groups per $\mathrm{nm}^{2}$ is shown at an ionic strength of $0.1-0.3 \mathrm{~mol} \cdot \mathrm{dm}^{-3}$ (see further details in Table $\mathrm{S} 1$ and original data in refs. 9,38-41). 
Table 1. Sequence, charge, isoelectric point, and hydrophilicity of the selected peptides,

$$
\text { identified by phage display. }{ }^{10}
$$

\begin{tabular}{clccc} 
Peptide name & \multicolumn{1}{c}{ Sequence } & Net charge at $\mathrm{pH}=7.4$ & $\mathrm{pI}^{\mathrm{a}}$ & Hydrophilicity $^{\mathrm{a}}$ \\
S1 & $\mathrm{K}^{+} \mathrm{LPGWSG} \cdot \mathrm{Cl}^{-}$ & +1 & $9.8 \pm 0.2$ & -0.3 \\
S2 & AFILPTG & 0 & $5.8 \pm 0.2$ & -1 \\
S3 & $\mathrm{LD}^{-} \mathrm{HSLHS} \cdot \mathrm{Na}^{+}$ & -1 & $6.1 \pm 0.1$ & -0.1
\end{tabular}

a Values close to zero correspond to hydrophilicity and values close to -1 hydrophobicity. Calculated according to ref. ${ }^{42}$.

\section{Recent Developments in Modeling and Simulation of Silica Interfaces}

A companion paper introduced a force field and a surface model database for silica to simulate bulk, surface, and interfacial properties in atomic resolution. ${ }^{37}$ This work discusses chemical bonding and surface features of silica in depth to enable quantitative studies of silicabiomolecular interfaces at the scale of $1 \mathrm{~nm}$ to $100 \mathrm{~nm}$ under realistic solution conditions. Major improvements in the force field include the chemically consistent representation of ionic versus covalent bonding in silica, incorporation of full details of surface chemistry, surface ionization, as well as validation of interfacial properties in $\sim 5 \%$ agreement with experiment, down from up to $500 \%$ error previously. Prior force fields often required fixed atoms to avoid collapse of the models in the simulation, neglected the $\mathrm{pH}$ dependence of the surface chemistry, and involved other drastic approximations so that even approximate predictions of specific binding of biomolecules were essentially impossible. ${ }^{43-56}$

The new, thermodynamically consistent silica parameters are compatible with comprehensive harmonic force fields for biopolymers, organic molecules, and inorganic compounds such as 
CHARMM, AMBER, PCFF, COMPASS, CVFF, and INTERFACE. ${ }^{26,} 37$ The compatibility enables insight into a limitless number of silica hybrid materials by the possible combination of thousands of distinct silica surface structures with billions of distinct biopolymers, surfactants, and receptor molecules across a wide range of concentrations and solution conditions. A surface model database covers experimentally observed surface chemistries of all types of silica and aids in the preparation of customized nanostructures for given conditions (Table S1) ${ }^{37}$

The novel features of the force field and of the surface model database are summarized more inclusively as follows: (1) full atom mobility, (2) reproduction of the lattice parameters of crystalline silica, (3) coverage of the full range of surface chemistry with $\mathrm{Q}^{2}, \mathrm{Q}^{3}, \mathrm{Q}^{4}$, amorphous, and porous environments, (4) coverage of the full range of surface ionization corresponding to surface type and $\mathrm{pH},(5)$ agreement of computed immersion energies, contact angles of water, and adsorption isotherms with laboratory measurements (using common SPC and TIP3P water models), (6) correlation of cation dissociation with measured $\zeta$-potentials as a function of $\mathrm{pH}$ and nanoparticle size, (7) full compatibility with many harmonic energy expressions (see above). These features are described in ref. ${ }^{37}$. The present contribution illustrates that the accurate reproduction of the structure and interfacial properties of pristine silica provides a solid foundation for realistic simulations of complex silica-organic and silica-biomolecular interfaces. The improvements in accuracy up to two orders of magnitude over earlier models $9,32,53,57-64$ result from the precise implementation of chemical details in the INTERFACE force field, ${ }^{26}$ as also shown for other inorganic-organic interfaces. ${ }^{9,} 21,25,29,30,65-72$ 


\section{Results and Discussion}

3.1. Specific Peptide Adsorption as a Function of pH. The three peptides shown in Table 1 and silica nanoparticles of $82 \mathrm{~nm}$ uniform size (Figure 1b) were chosen to investigate the impact of $\mathrm{pH}$ on specific peptide adsorption. Extensive experimental characterization of the silica surfaces by BET, TGA, and $\zeta$-potential measurements as well as of peptide adsorption by adsorption isotherms is available (Figures $\mathrm{S} 1$ to $\mathrm{S} 3$ ). ${ }^{10,42}$ The nanoparticle surfaces at $\mathrm{pH}$ values of 3, 5, 7.4, and 8.5 were represented by regular $Q^{3}$ silica surfaces with specific degrees of ionization of silanol groups $\equiv \mathrm{Si}-\mathrm{OH}$ to siloxide groups $\equiv \mathrm{SiO}^{-} \ldots \mathrm{Na}^{+}$(Figure 2$) .{ }^{10}$ The degrees of ionization are $0 \%, 9 \%, 18 \%$, and $50 \%$, respectively (see details in Table S1). ${ }^{37}$ The chemical appearance of these surfaces differs significantly, leading to an amount of dissociated cations of $0,0.27 .0 .45$, and 0.30 cations per $\mathrm{nm}^{2}$, whereby the value of $50 \%$ silanol ionization corresponds to maximum ionization of the silica surface somewhat above $\mathrm{pH} 8.5 .{ }^{37}$ The $\mathrm{pH}$ values of the peptides were represented by the appropriate charge state of $\mathrm{pH}$-sensitive residues ( $\mathrm{N}$-terminus, $\mathrm{K}, \mathrm{D}, \mathrm{H}, \mathrm{N}$-terminus) and addition of oppositely charged ions to maintain overall charge neutrality when needed $\left(\mathrm{Na}^{+}, \mathrm{Cl}^{-}\right)$. 

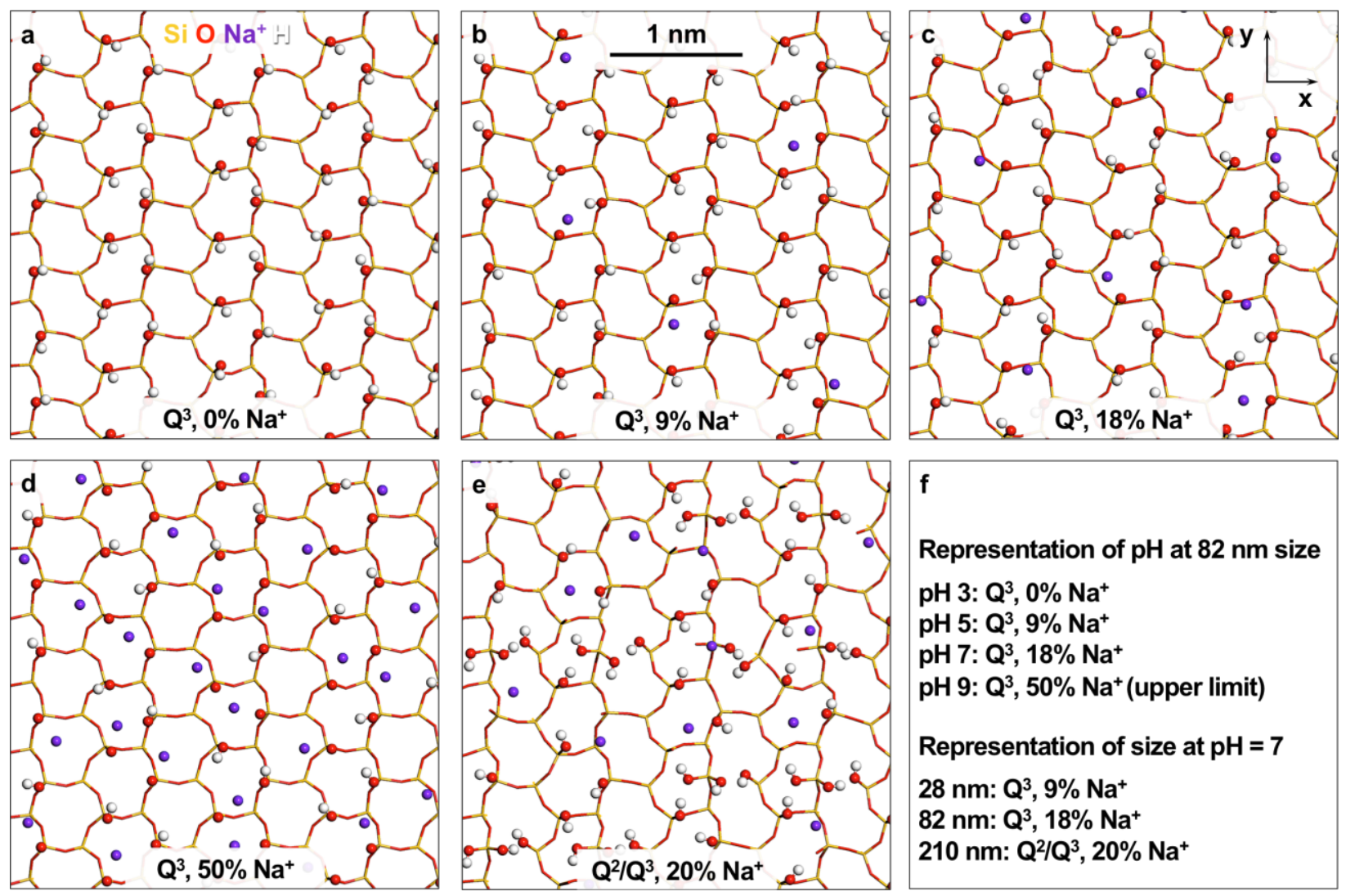

Figure 2. Silica model surfaces for different $\mathrm{pH}$ and particles of different size in top view. (a-d) Regular $\mathrm{Q}^{3}$ surfaces with $4.7 \mathrm{SiO}(\mathrm{H}, \mathrm{Na})$ groups per $\mathrm{nm}^{2}$ and different amount of $\mathrm{SiO}^{-} \mathrm{Na}^{+}$groups represent $\mathrm{pH}$ values of $3,5,7$, and 9 for $82 \mathrm{~nm}$ size nanoparticles. (e) The regular $\mathrm{Q}^{2} / \mathrm{Q}^{3}$ surface with $6.5 \mathrm{SiO}(\mathrm{H}, \mathrm{Na})$ groups per $\mathrm{nm}^{2}$ and $20 \%$ ionization represents $210 \mathrm{~nm}$ size particles at $\mathrm{pH} 7$. High area density of both $\mathrm{SiOH}$ and of $\mathrm{SiO}^{-} \mathrm{Na}^{+}$groups results in stronger adsorption of all peptides. Models for particles of $28 \mathrm{~nm}$ and $82 \mathrm{~nm}$ size at $\mathrm{pH} 7$ correspond to (b) and (c). (f) Summary of correspondence of chosen models to $\mathrm{pH}$ and particle size near physiological ionic strength.

Large-scale parallel molecular dynamics simulations of the three peptides on the silica surfaces were then carried out, including multiple independent start conformations, thermal annealing, and total simulations times in excess of 20 ns (Figures 3 and 4, see details in section 
S1). ${ }^{73}$ A very good correlation between the amount of adsorbed peptides in the adsorption isotherm (Figure $3 a)^{10}$ and the percentage of time close to the surface in the simulations was observed (Figure 3b) without any further assumptions. Close contact of the peptides was thereby defined as a distance of less than $3 \AA$ from the surface oxygen atoms. Computed adsorption energies $E_{C}$ and computed adsorption free energies $\Delta F_{C}$ also correlate with the adsorbed amount of peptide in experiment (Table 2). Values further below zero correspond to attraction and a larger amount adsorbed. Nearly equal values of adsorption energies and adsorption free energies are notable, whereby computed adsorption free energies are shown only for the cationic peptide KLPGWSG due to the high computational cost of umbrella sampling and steered MD (Table 2 and section S1). Using the relation $F_{C}=E_{C} T S_{C}$, it is found that net entropic contributions to adsorption $-T \Delta S_{C}$ are small, essentially within the uncertainty of $\pm 2 \mathrm{kcal} / \mathrm{mol}$. Therefore, the adsorption energy $E_{C}$ is a good first approximation for the free energy of binding $\Delta F_{C}$ of short peptides. Similar suggestions were made earlier for the binding of peptides on metal and silica surfaces in aqueous solution. ${ }^{9,22,67,73}$ The present quantitative data therefore confirm a certain entropy loss of the peptide upon adsorption due to decreased conformational freedom, which is compensated, or slightly overcompensated, by the release of surface-bound water that gains translational and rotational mobility. Computed binding free energies $\Delta F_{C}$ of 0 , $-1,-6$, and $-8 \mathrm{kcal} / \mathrm{mol}( \pm 0.5 \mathrm{kcal} / \mathrm{mol})$ on $0 \%, 9 \%, 18 \%$, and $50 \%$ ionized surfaces also agree with binding free energies $\Delta F_{A}$ in a range -4 to $-7 \mathrm{kcal} / \mathrm{mol}$ for peptide KLPGWSG derived from the adsorption isotherms (Table S2). The experimental values $\Delta F_{A}$ were derived from approximate binding constants $K_{A}$ according to $\Delta F_{A}=-R T \ln K_{A}$, and uncertainties are also difficult to reduce below $\pm 2 \mathrm{kcal} / \mathrm{mol}$ (section S1.4). ${ }^{10}$ In addition, computed adsorption energies 
correlate with the experimental threshold concentration of peptides to achieve significant adsorption (section S3).

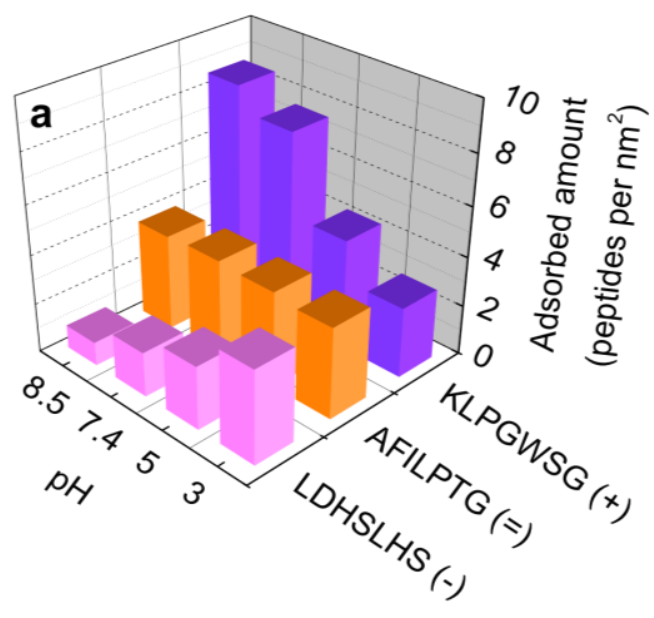

Experiment

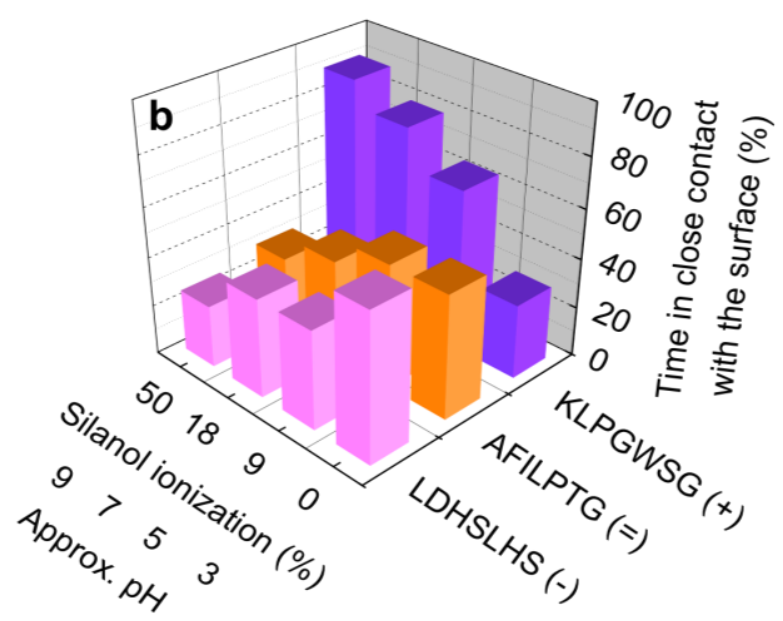

Simulation

Figure 3. Peptide adsorption on silica nanoparticles of average diameter $82 \mathrm{~nm}$ with 4.7 silanol groups per $\mathrm{nm}^{2}$ as a function of $\mathrm{pH}$ by measurement and simulation. (a) Adsorbed amount of three peptides of different charge as a function of $\mathrm{pH}$ at $1 \mathrm{mM}$ initial concentration (from ref. ${ }^{10}$ ). (b) Percentage of time the same peptides spend in close contact with $\mathrm{Q}^{3}$ silica surfaces of different ionization according to simulation $(<3 \AA)$. Different $\mathrm{pH}$ states of the surface are embodied in the model by differences in silanol ionization. 
Table 2. Computed energy of adsorption of the peptides on $\mathrm{Q}^{3}$ silica surfaces of different $\mathrm{pH}$ value according to molecular dynamics simulation ( $\pm 2 \mathrm{kcal} / \mathrm{mol})$. Computed free energies of adsorption are also shown for KPLGWSG $( \pm 0.5 \mathrm{kcal} / \mathrm{mol})$.

\begin{tabular}{lcccc}
\multicolumn{1}{c}{ Peptide } & \multicolumn{4}{c}{ Adsorption energy (kcal/mol $)$} \\
\cline { 2 - 5 } (charge at $\mathrm{pH} 7)$ & $\mathrm{pH} 3$ & $\mathrm{pH} \sim 5$ & $\mathrm{pH} 7.4$ & $\mathrm{pH}>8.5$ \\
& $(0 \%$ ionized $)$ & $(9 \%$ ionized $)$ & $(18 \%$ ionized $)$ & $(50 \%$ ionized $)$ \\
KLPGWSG (+) & -1 & -1 & -3 & -7 \\
KLPGWSG (+) - Free energy & 0 & -1 & -6 & -8 \\
AFILPTG (=) & +3 & +1 & +3 & +4 \\
LDHSLHS (-) & -2 & +1 & +2 & +4
\end{tabular}

A major benefit from the simulation is access to structural information on the atomic scale (Figure 4 and Table 3). Visualizations (Figure 4) and time-averaged information on the proximity of individual residues and residence times on the surface (Table 3) explain the mechanism of selective adsorption. The positively charged peptide KLPGWSG is more attracted to surfaces at higher $\mathrm{pH}$ that carry an increased negative charge per area (Figure 3). On the $50 \%$ and $18 \%$ ionized surfaces, i.e., at $\mathrm{pH} 9$ and 7 , the peptide is anchored to the surface by the ammonium groups of the $\mathrm{N}$-terminal and the $\mathrm{K} 1$ side chain for more than $80 \%$ of the time (Figure 4a). At lower ionization of $9 \%$ and $0 \%$, i.e. at $\mathrm{pH} 5$ and 3, electrostatic interactions through ion pairing are diminished and hydrogen bonds of the $\mathrm{OH}$ groups of S6 and of ammonium groups on $\mathrm{N}$-terminal $\mathrm{K} 1$ with the silica surface increasingly contribute to adsorption (Figure 4b, c). In addition, close contacts of L2, P3, and W5 side chains with the surface are seen (Table 3). Hydrophobic residues have thereby no intrinsic affinity to the silica surface; their 
surface attachment mainly diminishes disruptions of the hydrogen-bonded structure of liquid water. Near-neutral silica surfaces therefore attract hydrophobic residues to concentrate unfavorable hydrophobic (van-der-Waals) interactions directly at the surface, however, hydration shells of siloxide ions and cations keep hydrophobic residues away on ionized silica surfaces. The time-averaged adsorbed conformation of the positively charged peptide KLPGWSG, therefore, changes from anchor-like with strong contribution by ammonium groups on highly negatively charged surfaces (Figure 4a) to flat-on arrangements with higher mobility (Figure 4c) and more contact of polar and hydrophobic functional groups on the less ionized surfaces (L2, P3, W5).

Adsorption of the overall neutral peptide AFILPTG was weaker than for KLPGWSG and statistically not affected by changes in surface ionization and $\mathrm{pH}$ (Figure 3). Interactions with the $50 \%$ ionized surface, which exceed the experimental surface charge, were found to be slightly more repulsive than in experiment (Table 3). On all other surfaces, the peptide was in contact with the silica surface at least $40 \%$ of the simulation time through the N-terminal ammonium group by electrostatic forces (ion pairing) as well as through hydrogen bonds that involve the carboxylate of the $\mathrm{C}$-terminal and the $\mathrm{OH}$ group in $\mathrm{T} 6$ in contact with surface silanol groups (Figure 4d). Additional hydrophobic interactions were observed through the phenyl ring in F2, the L4 side chain, and the ring of P5 in agreement with experimental observations (Figure 4e and Table 3). ${ }^{10}$

The negatively charged peptide LDHSLHS showed less time in contact with most surfaces than the other two peptides and adsorption decreased with higher density of negative charge (Figure 3, Table 3). This peptide also notably changes its own charge from approximately -1.5 at $\mathrm{pH} 8.5$ to +2 at $\mathrm{pH} 3 .{ }^{42}$ Direct contact with the highly ionized surface at $\mathrm{pH} 8.5$ amounted to 
only $20 \%$ of simulation time (Figure $4 \mathrm{f}$ ) and increased to above $40 \%$ of simulation time for $18 \%$ and 9\% ionized silica surfaces respectively (Figure 4g). The N-terminus of L1 and hydroxyl groups in $\mathrm{S7}$, as well as some hydrophobic groups approach the surface at lower $\mathrm{pH}$ (Table 3). At the point of zero charge, the peptide is in close contact with the surface for more than $60 \%$ of simulation time, including protonated H3, H6, and temporarily all residues (Figure 4h). 

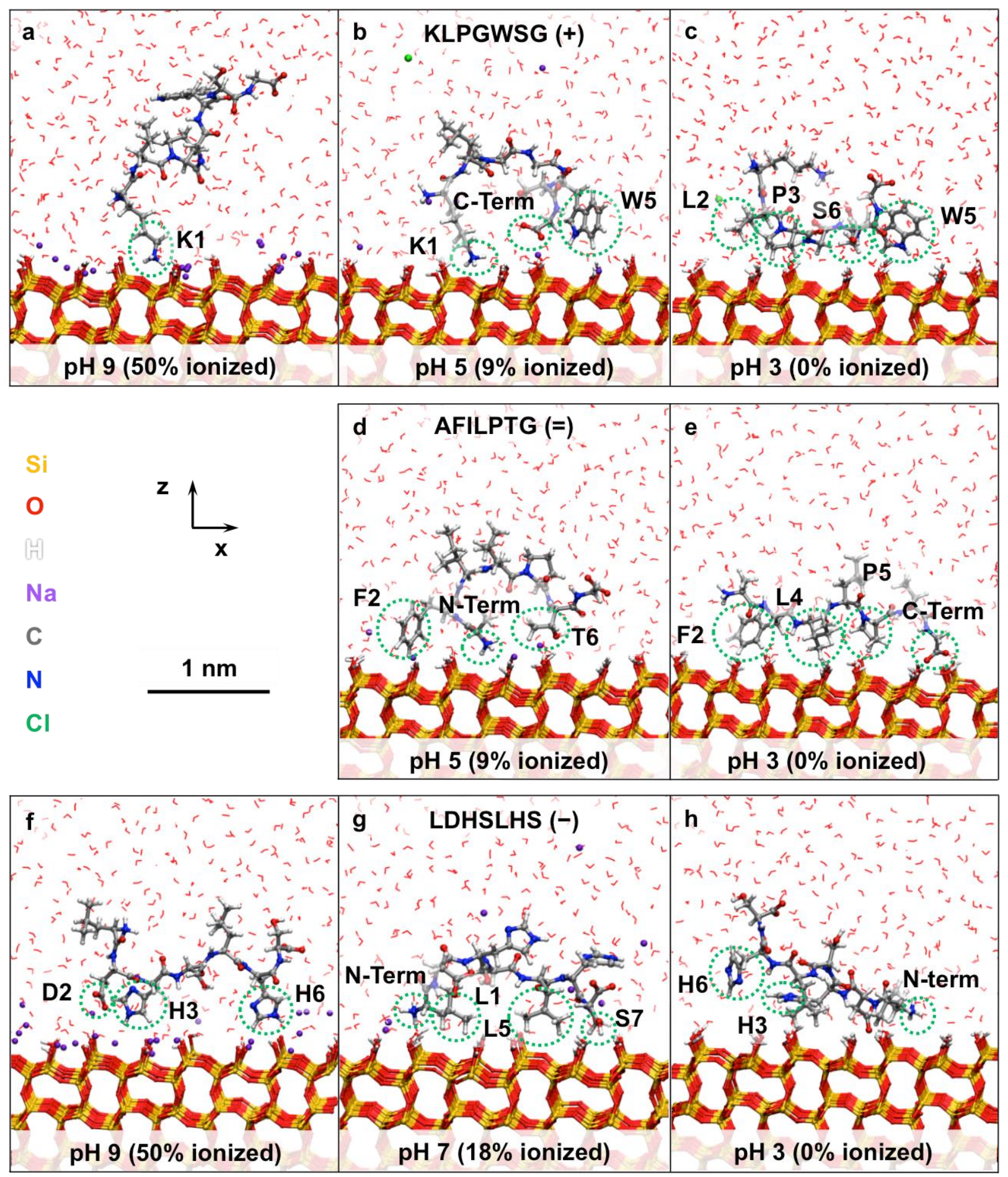

Figure 4. Selected conformation of three peptides of different charge on $\mathrm{Q}^{3}$ silica surfaces for a series of $\mathrm{pH}$ values according to simulation. The surfaces represent silica particles of $82 \mathrm{~nm}$ size with 4.7 $\mathrm{SiO}(\mathrm{H}, \mathrm{Na})$ groups per $\mathrm{nm}^{2}$ and variable ionization. (a-c) The positively charged peptide 
KLPGWSG, (d,e) the overall neutral peptide AFILPTG, (f-h) the negatively charged peptide LDHSLHS. Amino acids with significant surface interactions are highlighted. Close contact with the surface as shown occurs between $>90 \%$ (a) and $20 \%$ (f) of time depending on affinity. 
Table 3. Adsorption strength of peptides bound to $\mathrm{Q}^{3}$ silica surfaces at different $\mathrm{pH}$ values, characterized by the percentage of simulation time in close contact with the surface, i.e., $<3 \AA$ vertical distance from the superficial layer of silanol oxygen atoms. Amino acids are ranked in the order of proximity to the surface with the closest first. Statistical uncertainties in time averages are $\pm 5 \%$.

\begin{tabular}{|c|c|c|c|c|c|c|c|c|}
\hline \multirow[t]{2}{*}{ Peptide } & \multicolumn{2}{|c|}{$\begin{array}{c}\mathrm{pH} 3 \\
(0 \% \text { ionized })\end{array}$} & \multicolumn{2}{|c|}{$\begin{array}{c}\mathrm{pH} 5 \\
(9 \% \text { ionized })\end{array}$} & \multicolumn{2}{|c|}{$\begin{array}{c}\mathrm{pH} \sim 7 \\
(18 \% \text { ionized })\end{array}$} & \multicolumn{2}{|c|}{$\begin{array}{c}\mathrm{pH}>8.5 \\
(50 \% \text { ionized })\end{array}$} \\
\hline & $\begin{array}{l}\text { Time } \\
\%\end{array}$ & Closest residues & $\begin{array}{l}\text { Time } \\
\%\end{array}$ & $\begin{array}{l}\text { Closest } \\
\text { residues }\end{array}$ & $\begin{array}{l}\text { Time } \\
\%\end{array}$ & $\begin{array}{l}\text { Closest } \\
\text { residues }\end{array}$ & $\begin{array}{l}\text { Time } \\
\%\end{array}$ & $\begin{array}{l}\text { Closest } \\
\text { residues }\end{array}$ \\
\hline $\begin{array}{l}\text { KLPGWSG } \\
(+)\end{array}$ & 30 & $\begin{array}{l}\text { W5, K1, N-terminal, } \\
\text { P3, S6 (hydrophobic } \\
\text { interactions dominate } \\
\text { at lower ionization) }\end{array}$ & 65 & $\begin{array}{l}\text { N-term, } \\
\text { K1 >>C term } \\
>\text { L2, W5, P3 }\end{array}$ & 75 & $\begin{array}{l}\text { N-term, K1 } \\
\text { >>C-term, } \\
\text { S6>>P3, } \\
\text { W5, L2 }\end{array}$ & 90 & $\begin{array}{l}\text { N-term, } \\
\text { K1>>C- } \\
\text { term>S6, } \\
\text { W5 }\end{array}$ \\
\hline $\begin{array}{l}\text { AFILPTG } \\
(=)\end{array}$ & 50 & $\begin{array}{l}\text { N-term, C-term, T6, } \\
\text { F2, L4, I3, P5 }\end{array}$ & 50 & $\begin{array}{l}\text { N-term>C- } \\
\text { term, T6, F2, } \\
\text { L4, I3, P5 }\end{array}$ & 40 & $\begin{array}{l}\text { N-term>C- } \\
\text { term, T6, F2, } \\
\text { L4, I3 }\end{array}$ & 30 & $\begin{array}{l}\text { N-term>C- } \\
\text { term, T6> } \\
\text { F2> L4, I3 }\end{array}$ \\
\hline $\begin{array}{l}\text { LDHSLHS } \\
(-)\end{array}$ & 60 & $\begin{array}{l}\text { N-term, C-term, S7, } \\
\text { D2, S4, H3, H6, L1, } \\
\text { L5 }\end{array}$ & 40 & $\begin{array}{l}\text { N-term, C- } \\
\text { term, S7, } \\
\text { D2, S4, H3 } \\
\text { H6, L1, L5 }\end{array}$ & 40 & $\begin{array}{l}\text { N-term, C- } \\
\text { term > S7, } \\
\text { D2, S4, H3, } \\
\text { H6, L1, L5 }\end{array}$ & 20 & $\begin{array}{l}\text { N-term, C- } \\
\text { term > S7, } \\
\text { D2, S4, H3, } \\
\text { H6, L1, L5 }\end{array}$ \\
\hline
\end{tabular}


In summary, molecular dynamics simulation with the new silica force field predicts peptide adsorption as a function of $\mathrm{pH}$ in remarkable correlation with experiment, and contributions to binding can be traced in atomic detail. Ion pairing, hydrogen bonds, and hydrophobic interactions, as well as conformation effects (especially for longer peptides and proteins) contribute to selective binding. ${ }^{9}$ Electrostatic and polar interactions are thereby stronger than hydrophobic interactions. Hydrophobic interactions become significant at lower degree of surface ionization and involve many binding sites throughout the peptide chain, driven by the separation of hydrophobic groups from the aqueous phase onto the surface. The contribution of each binding mode can be quantified and visualized for specific surface conditions and biomolecules. Changes in proton distribution on the peptides such as across L1, D3, H3, H6, and S7 residues of LDHSLHS are also essential to understand selective adsorption as a function of pH. Future studies may also explore simulations with multiple adsorbed peptides corresponding to higher initial peptide concentration.

3.2. Specific Peptide Adsorption as a Function of Silica Nanoparticle Size. In this section, it is shown how the same approach can be applied to understand specific peptide binding to silica particles of variable size (Figure 1). Silica nanoparticles of different synthetic origin are generally distinguishable by differences in surface chemistry and topology, and in turn attract highly dissimilar peptides. ${ }^{9}, 10,37,42,74$ A common example is Stöber-type silica nanoparticles of different size that are produced using different amounts of ammonia to hydrolyze precursors, and in turn attract peptides of less than $20 \%$ sequence similarity at the same $\mathrm{pH}$ value. ${ }^{9} \zeta$-potential measurements show that larger silica nanoparticles exhibit more surface ionization and a lower point of zero charge (Figures 1 and S1), thus attracting peptides of higher positive charge (higher isoelectric point pI). ${ }^{9}$ 37, 42 Qualitatively, this relation was previously verified by molecular 
simulations, which showed that combinatorially selected peptides binding to $82 \mathrm{~nm}$ particles (pep 1, KSLSRHDHIHHH, pI 8.8) were less attracted to $450 \mathrm{~nm}$ particles, and combinatorially selected peptides binding to $450 \mathrm{~nm}$ particles (pep4, MHRSDLMSAAVR, pI 9.4) were less attracted to $82 \mathrm{~nm}$ particles. ${ }^{9}$ The surfaces were then approximated as ionized $\mathrm{Q}^{3}$ environments for $82 \mathrm{~nm}$ particles and as ionized $\mathrm{Q}^{2}$ environments for $450 \mathrm{~nm}$ particles, respectively, using the PCFF-SILICA force field (please refer to Table S1 for details of the surface chemistry of silica particles of different chemistry and size). ${ }^{37}$

Recent further characterization by TEM, SEM, BET, BJH, TGA, XPS, and $\zeta$-potential measurements quantified size-dependent differences in surface chemistry, including the area density of silanol groups (silanol number), the degree of ionization, surface morphology, and porosity (Figure 5a, see details in section S2). ${ }^{42}$ Therefore, silica nanoparticles of 28, 82, and 210 $\mathrm{nm}$ size and the same set of peptides as above (Table 1) were chosen to evaluate the influence of particle size on specific peptide adsorption at a constant $\mathrm{pH}$ value of 7.4 (Figure 5b). Quantitative affinity predictions by molecular dynamics simulations are in good agreement with measurements (Figure 5c), although differences for poorly defined surfaces of $28 \mathrm{~nm}$ particles are also noted.

A critical aspect hereby is the use of realistic surface models. TEM and SEM measurements show the irregular, "spongy" structure of $28 \mathrm{~nm}$ nanoparticles in contrast to the well-developed spherical geometry of larger particles (Figure 1a-d). Due to the lack of specific information, regular surfaces were nevertheless assumed for simplicity. For $82 \mathrm{~nm}$ and $210 \mathrm{~nm}$ particles with some mesoporosity or negligible porosity, respectively, regular surface topography on the $5 \mathrm{~nm}$ scale is a good approximation. Differences in total $\mathrm{SiOH}$ area density and surface acidity according to TGA and $\zeta$-potential measurements are significant (Figure 5a) ${ }^{42}$ and were 
appropriately matched to the area density of silanol groups and ionization in the surface models (Figure 2). The small and medium size particles of $18 \mathrm{~nm}$ and $82 \mathrm{~nm}$ size were accordingly represented by regular $\mathrm{Q}^{3}$ surfaces with a silanol density of 4.7 groups per $\mathrm{nm}^{2}$ with $9 \%$ and $18 \%$ ionization, respectively, consistent with data about the pzc and surface titration (Table S1). ${ }^{9,38-41}$ The nanoparticles of $210 \mathrm{~nm}$ size were represented by a mixed $\mathrm{Q}^{2} / \mathrm{Q}^{3}$ surface with a silanol density of 6.5 groups per $\mathrm{nm}^{2}$ and $20 \%$ ionization, accounting for higher silanol density and lower pzc. The cation density per unit area was thus 54\% higher in $210 \mathrm{~nm}$ particles than in 82 $\mathrm{nm}$ particles. Nanoparticles of $500 \mathrm{~nm}$ size could be represented by the same mixed $\mathrm{Q}^{2} / \mathrm{Q}^{3}$ surface with $\sim 30 \%$ ionization $\left(2.0 \mathrm{SiO}^{-} \mathrm{Na}^{+}\right.$groups per $\mathrm{nm}^{2}$ ), which further increases peptide adsorption without a significant change in $\zeta$-potential. ${ }^{37}$

Details of the adsorption mechanism of the peptides as a function of particle size can be inferred from the percentage of time in contact with the surface (Figure 5), conformations in contact with the surface (Figure 6), and the ranked list of proximity of individual residues (Table S3). Adsorption of all three peptides increased towards larger particles, i.e., towards higher surface ionization at $\mathrm{pH} \sim 7.4$. The variable surface charge of Stöber-type silica particles of different size tunes the adsorption mechanism and selective binding of biomolecules similar to the effect of variable $\mathrm{pH}$ (Figure 2).

On the surfaces attributed to the largest particles $(210 \mathrm{~nm})$, binding is dominated by electrostatic interactions (Figure 6a, d, g and Table S3). Also, the contribution by hydrogen bonds was significant due to the high total silanol density and surface acidity of the silica surfaces. N-termini of all peptides and the positively charged ammonium group of $\mathrm{K} 1$ in KLPGWSG were the primary functional groups that account for peptide adsorption. Hydrogen bonds also involved C-termini in all peptides for significant percentages of time, as well as S6 in 
KLPGWSG, T6 in AFILPTG, and S7, D2, S4, H3, and H6 in LDHSLHS. Weaker, intermittent hydrophobic interactions were also observed as a result of peptide exclusion from the solution towards the surface, particularly for the AFILPTG peptide with hydrophobic moieties in side chains of F2, I3, L4, P5, and T6 residues. Notably, even the negatively charged peptide LDHSLHS was somewhat drawn to the surface, and hydrophobic groups in all peptides were comparatively distant from the surface due to strong surface-water interactions.

On the surfaces attributed to smaller $82 \mathrm{~nm}$ particles, represented by pure $\mathrm{Q}^{3}$ models with 4.7 $\mathrm{SiO}(\mathrm{H}, \mathrm{Na})$ and $18 \%$ ionization, the significance of ion pairing and hydrogen bonds decreased, resulting in lower affinity of all three peptides (Figure 6b, e, h and Table S3). The most attracted residues are similar to those seen for $210 \mathrm{~nm}$ particles, however, the percentage of time being anchored and exposed to the surface was reduced. Amongst the three peptides, the adsorption of AFILPTG on the surface of $82 \mathrm{~nm}$ particles had the sharpest decrease in binding from $\sim 70 \%$ on to $\sim 40 \%$ of time in close contact, which was mainly associated with the decrease in attraction of the peptide N-terminus.

On silica surfaces representing $28 \mathrm{~nm}$ nanoparticles, the adsorption of peptide KLPGWSG decreased somewhat further due to less electrostatic attractions. Adsorption of AFILPTG occurred intermittently for $\sim 50 \%$ of simulation time primarily mediated by hydrophobic groups, and proximity of LDHSLHS was observed $\sim 40 \%$ of simulation time through hydrogen bonds (Figure $6 \mathrm{c}, \mathrm{f}, \mathrm{i}$ ). The adsorption mechanism on the surfaces of smaller silica particles involved less ion pairing, less hydrogen bonds, and increasingly hydrophobic interactions, similar to adsorption at low $\mathrm{pH}$.

As mentioned above, the experimentally measured adsorption for the $28 \mathrm{~nm}$ samples is substantially lower than the affinity predicted by molecular dynamics simulation on idealized 
regular surfaces (Figure 5b,c). Thereby, the relative trend in peptide attraction is still consistent between measurements and simulation. The authors believe that structural irregularities (Figure 1a) make much of the internal, nitrogen-accessible surface area in BET measurements unavailable to peptide adsorption, which was reported relative to the BET area in measurements (Figure 5, Figure S3, section S2). Previous studies also report poor definition and plasticity, as well as incomplete dissociation of organic precursor groups for Stöber-type silica particles smaller than $50 \mathrm{~nm} .{ }^{75}$ The disproportionately weak adsorption of peptides in experiment (Figure S3) may thus be related to overestimated surface area and partly to the presence of some residual hydrophobic organic groups on the silica surface (see more details in section S4). Certainly, more work is needed to consolidate poorly defined silica nanostructures with representative models.

In summary, computational predictions of biomolecular binding as a function of particle size correlate well with measurements. Close correspondence of true surface chemistry and morphology to the representation in models is thereby essential. The demonstrated sensitivity enables binding predictions for numerous existing and novel silica morphologies, as well as the elucidation of irregular silica structural models consistent with experimental information on structure and binding that often remains incomplete. 
$\mathbf{a}$

Information from experiment

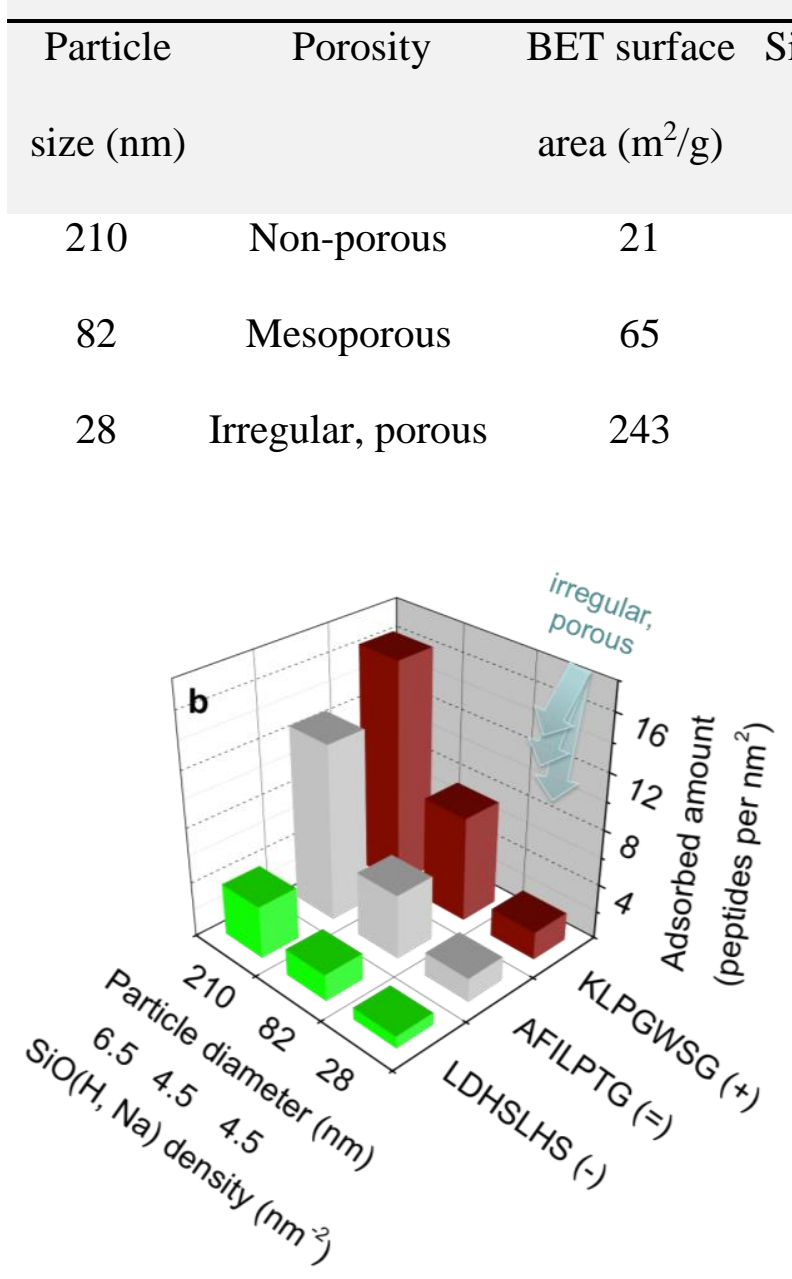

Experiment
Model

$\mathrm{SiO}(\mathrm{H}, \mathrm{Na})$ Ionization

$$
\left(\mathrm{nm}^{-2}\right)
$$

$6.5(1) \quad 2.2(2) \quad 6.5\left(\mathrm{Q}^{2} / \mathrm{Q}^{3}\right)$

20

$4.5(1) \quad 2.4(2)$

$4.7\left(\mathrm{Q}^{3} \mathrm{np}\right)$

18

$4.5(1) \quad 3.1(2)$

$4.7\left(\mathrm{Q}^{3} \mathrm{np}\right)$

9

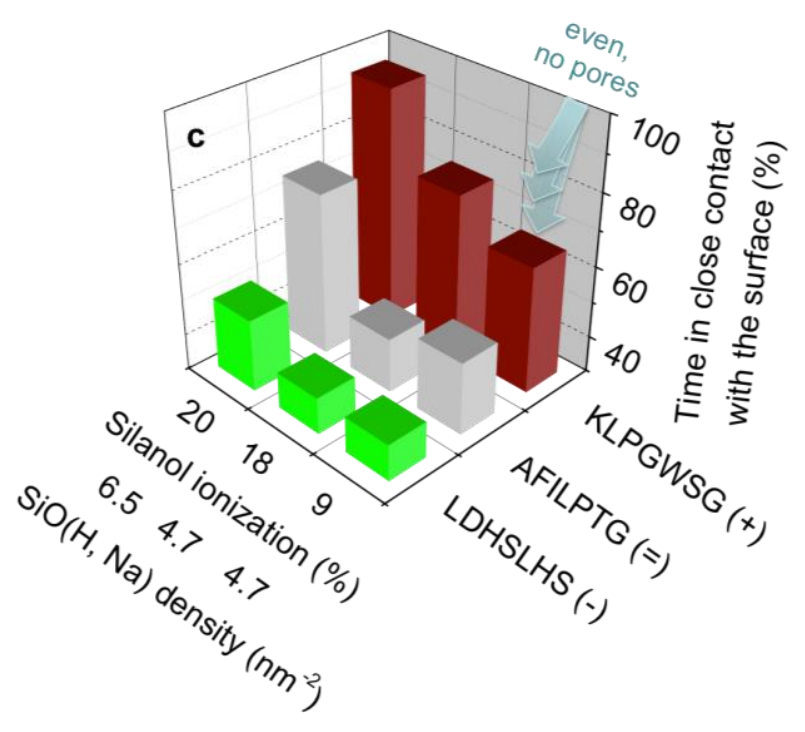

Simulation

Figure 5. Adsorption spongy of peptides on silica nanoparticles of different size with particular surface features in experiment and simulation at $\mathrm{pH}=7.4$. (a) Nanoparticle characteristics (from ref. ${ }^{42}$ ) and corresponding model assumptions (np=non-porous). (b) Adsorbed amount of three peptides of different charge per BET surface area in experiment at $1 \mathrm{mM}$ initial peptide concentration. (c) Percentage of time that peptides are in direct contact with the surface $(<3 \AA)$ in the simulation. The agreement is good, and the high impact of irregularity on adsorption is seen 
for the $28 \mathrm{~nm}$ particles (poor particle definition in experiment $\mathrm{b}$ versus ideal regular surfaces in simulation c).
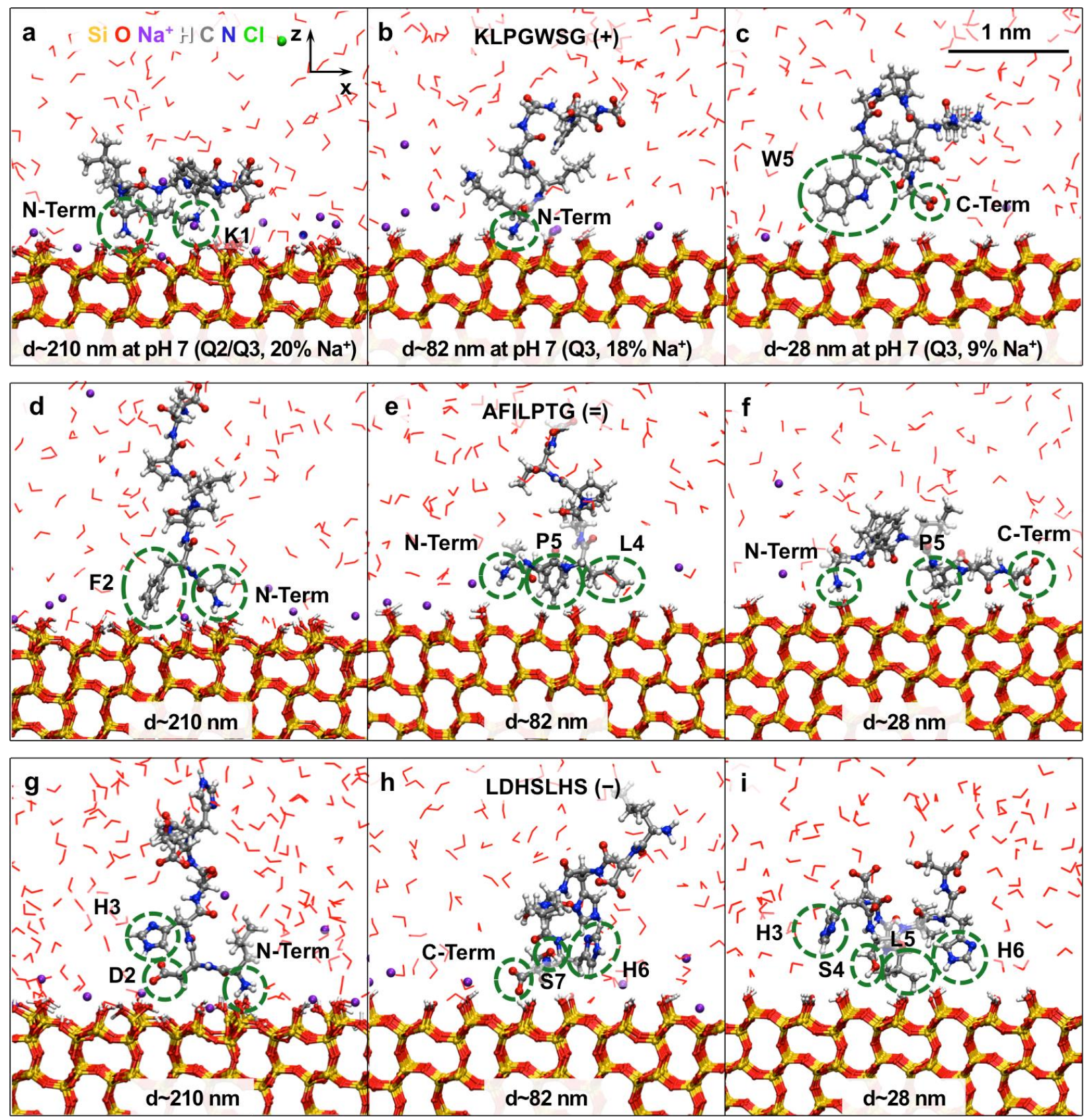

Figure 6. Selected conformations of three peptides of different charge on silica surfaces representing nanoparticles of $210 \mathrm{~nm}, 82 \mathrm{~nm}$, and $28 \mathrm{~nm}$ sizes at $\mathrm{pH} \sim 7$. (a-c) The positively charged peptide KLPGWSG, (d-f) the neutral peptide AFILPTG, (g-i) the negatively charged 
peptide LDHSLHS. Amino acids with significant surface interaction are highlighted. The actual percentage of time in close contact with the surface varies between $90 \%$ (a) and $40 \%$ (e, h, and i) depending on affinity (see Table S3).

\section{Conclusions}

In conclusion, specific silica surface models of different degree of ionization were employed to study the adsorption of various peptides as a function of $\mathrm{pH}$ and particle size. Data from adsorption isotherms and from molecular simulation were found to be in very good correlation, showing that the INTERFACE-CHARMM force field and a surface model database ${ }^{26,37}$ are suitable to predict selective adsorption in atomic resolution.

The results also reiterate the mechanism of adsorption and rationally explain the contribution

of different factors in the context of the surface chemistry and charge states of silica and peptides. The contributions to selective adsorption involve ion pairing, hydrogen bonds, conformation effects, and hydrophobic interactions. A higher $\mathrm{pH}$ value in the solution results in higher negative charge density on the silica surface and shifts adsorption towards positively charged peptides, diminishing the attraction of negatively charged peptides, the influence of hydrogen bonds and hydrophobic interactions. $\mathrm{pH}$ had little effect on neutral peptides, which were more weakly bound by hydrogen bonds and hydrophobic interactions. At lower $\mathrm{pH}$, binding differentials between all peptides diminish and hydrophobic residues increasingly interact with the surface. Binding of the same peptides to three batches of silica nanoparticles of different diameters showed stronger adsorption on larger particles with higher surface silanol density $\left(\mathrm{Q}^{2} / \mathrm{Q}^{3}\right.$ environments), surface ionization, and absence of porosity. Weaker hydrophobic interactions on less ionic surfaces originate from the exclusion of peptides from the aqueous 
phase to minimize disruptions of the network of hydrogen bonds. The different contributions to binding are tunable in customized proportions and can be evaluated by molecular dynamics simulation. Poor definition and "sponginess" of small (28 nm silica) nanoparticles showed much reduced peptide attraction, in part related to limited accessibility of the BET surface area.

While the force field accurately predicts binding of biomolecules for the chosen conditions, the representation of silica surface structure in the models must be handled with care. The feasibility of predictive simulations can be applied to a wide range of surface chemistry and topology, multiplied by a huge number of specific biomolecules and adsorbents, to engineer silica materials for desired performance at the atomic scale. In combination with new synthesis and characterization methods, computations can reduce the time spent on trial-and-error based chemistry. The models can be applied to screen the binding and release of drug molecules to customized silica nanostructures, evaluate silica nanoparticle interactions with specific receptors on cell surfaces, track the adsorption of gases in silica glasses and zeolites (using complementary parameters for aluminosilicates), ${ }^{26}$ and assess the self-assembly of silica nanostructures, polymer and hydrogel composites at given $\mathrm{pH}$, ionic concentration, and temperature.

\section{Acknowledgement}

We acknowledge support from the Air Force Research Laboratory, UES, Inc., the Air Force Office of Scientific Research (F. S. E. and H. H. via FA8650-09-D-5037, C. C. P. via FA9550-10-1-0024 and FA9550-13-1-0040), the National Science Foundation (DMR-0955071), the University of Akron, and the Ohio Supercomputing Center for the allocation of computational resources. 
Supporting Information Available: Complete details of computational methods, experimental methods, experimental data for model validation, additional discussion of specific peptide binding, as well as supporting Figures and Tables. This information is available free of charge at http://pubs.acs.org/.

\section{References}

1. Hoffmann, F.; Cornelius, M.; Morell, J.; Froba, M. Angew. Chem. Int. Ed. 2006, 45, 3216-3251.

2. Iler, R. K., The Chemistry of Silica: Solubility, Polymerization, Colloid and Surface Properties, and Biochemistry. John Wiley \& Sons: New York, 1979.

3. Slowing, II; Trewyn, B. G.; Giri, S.; Lin, V. S. Y. Adv. Funct. Mater. 2007, 17, 12251236.

4. Mackowiak, S. A.; Schmidt, A.; Weiss, V.; Argyo, C.; von Schirnding, C.; Bein, T.; Bräuchle, C. Nano Lett. 2013, 13, 2576-2583.

5. Hildebrand, M. Chem. Rev. 2008, 108, 4855-4874.

6. Kaehr, B.; Townson, J. L.; Kalinich, R. M.; Awad, Y. H.; Swartzentruber, B. S.; Dunphy, D. R.; Brinker, C. J. Proc. Natl. Acad. Sci. U.S.A. 2012, 109, 17336-17341.

7. Kröger, N.; Lorenz, S.; Brunner, E.; Sumper, M. Science 2002, 298, 584-586.

8. Patwardhan, S. V. Chem. Comm. 2011, 47, 7567-7582.

9. $\quad$ Patwardhan, S. V.; Emami, F. S.; Berry, R. J.; Jones, S. E.; Naik, R. R.; Deschaume, O.;

Heinz, H.; Perry, C. C. J. Am. Chem. Soc. 2012, 134, 6244-6256.

10. Puddu, V.; Perry, C. C. ACS Nano 2012, 6, 6356-6363.

11. Sarthou, G.; Timmermans, K. R.; Blain, S.; Treguer, P. J. Sea Res. 2005, 53, 25-42. 
12. Sumper, M.; Brunner, E. Adv. Funct. Mater. 2006, 16, 17-26.

13. Cha, J. N.; Stucky, G. D.; Morse, D. E.; Deming, T. J. Nature 2000, 403, 289-292.

14. Kröger, N.; Deutzmann, R.; Sumper, M. Science 1999, 286, 1129-1132.

15. Muller, W. E. G.; Schroder, H. C.; Burghard, Z.; Pisignano, D.; Wang, X. H. Chem. Eur. J. 2013, 19, 5790-5804.

16. Patwardhan, S. V.; Clarson, S. J.; Perry, C. C. Chem. Commun. 2005, 1113-1121.

17. Perry, C. C.; Patwardhan, S. V.; Deschaume, O. Biochem. Soc. Trans. 2009, 37, 687-691.

18. Rimola, A.; Costa, D.; Sodupe, M.; Lambert, J.-F.; Ugliengo, P. Chem. Rev. 2013, 113, 4216-4313.

19. Stober, W.; Fink, A.; Bohn, E. J. Colloid Interface Sci. 1968, 26, 62-69.

20. Vigil, G.; Xu, Z. H.; Steinberg, S.; Israelachvili, J. J. Colloid Interface Sci. 1994, 165, 367-385.

21. Coppage, R.; Slocik, J. M.; Ramezani-Dakhel, H.; Bedford, N. M.; Heinz, H.; Naik, R. R.; Knecht, M. R. J. Am. Chem. Soc. 2013, 135, 11048-11054.

22. Feng, J.; Pandey, R. B.; Berry, R. J.; Farmer, B. L.; Naik, R. R.; Heinz, H. Soft Matter 2011, 7, 2113-2120.

23. Heinz, H. Clay Miner. 2012, 47, 205-230.

24. Heinz, H.; Castelijns, H. J.; Suter, U. W. J. Am. Chem. Soc. 2003, 125, 9500-9510.

25. Heinz, H.; Koerner, H.; Anderson, K. L.; Vaia, R. A.; Farmer, B. L. Chem. Mater. 2005, 17, 5658-5669.

26. Heinz, H.; Lin, T.-J.; Mishra, R. K.; Emami, F. S. Langmuir 2013, 29, 1754-1765.

27. Heinz, H.; Suter, U. W. J. Phys. Chem. B 2004, 108, 18341-18352.

28. Heinz, H.; Suter, U. W.; Leontidis, E. J. Am. Chem. Soc. 2001, 123, 11229-11236. 
29. Mishra, R. K.; Flatt, R. J.; Heinz, H. J. Phys. Chem. C 2013, 117, 10417-10432.

30. Ruan, L.; Ramezani-Dakhel, H.; Chiu, C.-Y.; Zhu, E.; Li, Y.; Heinz, H.; Huang, Y. Nano Lett. 2013, 13, 840-846.

31. Ugliengo, P.; Sodupe, M.; Musso, F.; Bush, I. J.; Orlando, R.; Dovesi, R. Adv. Mater. 2008, 20, 4579-4583.

32. Schneider, J.; Ciacchi, L. C. J. Am. Chem. Soc. 2012, 134, 2407-2413.

33. Wright, L. B.; Walsh, T. R. Phys. Chem. Chem. Phys. 2013, 15, 4715-4726.

34. Calzolari, A.; Cicero, G.; Cavazzoni, C.; Di Felice, R.; Catellani, A.; Corni, S. J. Am. Chem. Soc. 2010, 132, 4790-4795.

35. Heinz, H. J. Phys.: Condens. Matter 2014, 26, 244105.

36. Liu, H.; Espe, M.; Modarelli, D. A.; Arias, E.; Moggio, I.; Ziolo, R. F.; Heinz, H. J. Mater. Chem. A 2014, 2, 8705-8711.

37. Emami, F. S.; Puddu, V.; Berry, R. J.; Varshney, V.; Patwardhan, S. V.; Perry, C. C.; Heinz, H. Chem. Mater. 2014, 26, 2647-2658.

38. Bolt, G. H. J. Phys. Chem. 1957, 61, 1166-1169.

39. Tadros, T. F.; Lyklema, J. J. Electroanal. Chem. Interfacial Electrochem. 1968, 17, 267275.

40. Zerrouk, R.; Foissy, A.; Mercier, R.; Chevallier, Y.; Morawski, J.-C. J. Colloid Interface Sci. 1990, 139, 20-29.

41. Sonnefeld, J. J. Colloid Interface Sci. 1996, 183, 597-599.

42. Puddu, V.; Perry, C. C. Langmuir 2014, 30, 227-233.

43. Sanders, M. J.; Leslie, M.; Catlow, C. R. A. Journal of the Chemical Society-Chemical Communications 1984, 1271-1273. 
44. van Beest, B. W. H.; Kramer, G. J. Phys. Rev. Lett. 1990, 64, 1955-1958.

45. Hill, J. R.; Sauer, J. J. Phys. Chem. 1994, 98, 1238-1244.

46. Cruz-Chu, E. R.; Aksimentiev, A.; Schulten, K. J. Phys. Chem. B 2006, 110, $21497-$ 21508.

47. Hassanali, A. A.; Singer, S. J. J. Phys. Chem. B 2007, 111, 11181-11193.

48. Hassanali, A. A.; Zhang, H.; Knight, C.; Shin, Y. K.; Singer, S. J. J. Chem. Theory Comput. 2010, 6, 3456-3471.

49. Lopes, P. E. M.; Murashov, V.; Tazi, M.; Demchuk, E.; MacKerell, A. D. J. Phys. Chem. B 2006, 110, 2782-2792.

50. Butenuth, A.; Moras, G.; Schneider, J.; Koleini, M.; Köppen, S.; Meißner, R.; Wright, L. B.; Walsh, T. R.; Ciacchi, L. C. Phys. Status Solidi B 2012, 249, 292-305.

51. Flikkema, E.; Bromley, S. T. Chem. Phys. Lett. 2003, 378, 622-629.

52. Goumans, T. P.; Wander, A.; Brown, W. A.; Catlow, C. R. Phys. Chem. Chem. Phys. 2007, 9, 2146-2152.

53. Skelton, A. A.; Fenter, P.; Kubicki, J. D.; Wesolowski, D. J.; Cummings, P. T. J. Phys. Chem. C 2011, 115, 2076-2088.

54. Garofalini, S. H. J. Chem. Phys. 1982, 76, 3189-3192.

55. Lockwood, G. K.; Garofalini, S. H. J. Chem. Phys. 2009, 131, 074703.

56. Pedone, A.; Malavasi, G.; Menziani, M. C.; Segre, U.; Musso, F.; Corno, M.; Civalleri, B.; Ugliengo, P. Chem. Mater. 2008, 20, 2522-2531.

57. Du, J.; Cormack, A. N. J. Am. Ceram. Soc. 2005, 88, 2532-2539.

58. Gambino, G. L.; Lombardo, G. M.; Grassi, A.; Marletta, G. J. Phys. Chem. B 2004, 108, 2600-2607. 
59. Lobel, K. D.; West, J. K.; Hench, L. L. J. Mater. Sci. Lett. 1996, 15, 648-650.

60. Rimola, A.; Civalleri, B.; Ugliengo, P. Langmuir 2008, 24, 14027-14034.

61. Yang, J. J.; Meng, S.; Xu, L. F.; Wang, E. G. Phys. Rev. B 2005, 71, 035413.

62. Oren, E. E.; Notman, R.; Kim, I. W.; Spencer, E. J.; Walsh, T. R.; Samudrala, R.;

Tamerler, C.; Sarikaya, M. Langmuir 2010, 26, 11003-11009.

63. Oren, E. E.; Tamerler, C.; Sahin, D.; Hnilova, M.; Seker, U. O. S.; Sarikaya, M.;

Samudrala, R. Bioinformatics 2007, 23, 2816-2822.

64. Argyris, D.; Cole, D. R.; Striolo, A. Langmuir 2009, 25, 8025-8035.

65. Feng, J.; Slocik, J. M.; Sarikaya, M.; Naik, R. R.; Farmer, B. L.; Heinz, H. Small 2012, 8, 1049-1059.

66. Fu, Y. T.; Heinz, H. Chem. Mater. 2010, 22, 1595-1605.

67. Heinz, H.; Farmer, B. L.; Pandey, R. B.; Slocik, J. M.; Patnaik, S. S.; Pachter, R.; Naik, R. R. J. Am. Chem. Soc. 2009, 131, 9704-9714.

68. Heinz, H.; Suter, U. W. Angew. Chem. Int. Ed. 2004, 43, 2239-2243.

69. Heinz, H.; Vaia, R. A.; Koerner, H.; Farmer, B. L. Chemistry of Materials 2008, 20, 6444-6456.

70. Heinz, H.; Vaia, R. A.; Krishnamoorti, R.; Farmer, B. L. Chem. Mater. 2007, 19, 59-68.

71. Jha, K. C.; Liu, H.; Bockstaller, M. R.; Heinz, H. J. Phys. Chem. C 2013, 117, 2596925981.

72. Mishra, R. K.; Fernández-Carrasco, L.; Flatt, R. J.; Heinz, H. Dalton Trans. 2014, 43, 10602-10616.

73. Heinz, H. J. Comput. Chem. 2010, 31, 1564-1568. 
74. Zhang, L.; D'Acunzi, M.; Kappl, M.; Imhof, A.; van Blaaderen, A.; Butt, H.-J.; Graf, R.; Vollmer, D. Phys. Chem. Chem. Phys. 2010, 12, 15392-15398.

75. Costa, C. A. R.; Leite, C. A. P.; Galembeck, F. J. Phys. Chem. B 2003, 107, 4747-4755. 


\section{TOC Illustration}
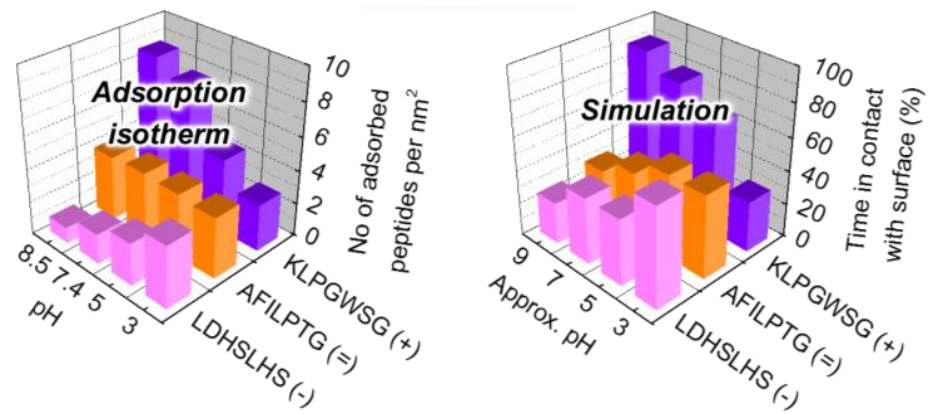

Page 33 of 33 